\title{
JIPES
} Journal of Indonesian Physical Education and Sport

P-ISSN 2442-4900 | E-ISSN 2461-1271

Vol. 6, No.2, December 2020, page 01-10

\section{DEVELOPMENT MODEL TRAINING BALL HANDLING FOR BASKETBALL ATHLETE SENIOR HIGH SCHOOL}

\author{
${ }^{1}$ Fakhri Fajrin Kurniawan \\ Universitas Muhammadiyah Cirebon \\ Author: fakhry.fajrin@umc.ac.id
}

\begin{abstract}
The goal of this research and development is to produce development model training ball handling basketball for basketball athlete Senior High School. This research and development also done to find out in depth about: increased mobility in basketball athlete Senior High School and know the success rate development model training ball handling basketball reviewed from : effective, efficient, traction, productivity of the athlete in doing ball handling basketball for basketball athlete Senior High School. This research and development uses qualitative and uses development research methods Research and Development (R \& D) Borg W. R and Gall. M. D. which uses 10 stages of development. The steps in this development research start from the following : (1) Research and information collecting, (2) Planning, (3) Develop preliminary form of product, (4) Preliminary field testing, (5) Main product revision, (6) Main field testing, (7) Operational product revision, (8) Operational field testing, (9) Final product revision, (10) Dissemination and implementation. Subjects in research and development is basketball athlete Senior High School. The results of this effectiveness test model training are uses statistical test with formula before-after (pre-test and post-test). The result of the pre-test calculation resulted in 781 with average 50,39 while the post-test resulted in 818 with average 52,77. Thus it can be concluded that the use of development model training ball handling basketball athlete Senior High School is effective in improving the individual skills of basketball athlete Senior High School.
\end{abstract}

\section{Keywords: Model Training, Ball Handling, Basketball.}

\section{INTRODUCTION}

Basketball game is a game played by two teams, each team consisting of five players. Where each player's position has generally been determined its position is as the following : player one as point guard (best ball handler), player two as shooting guard (best outside shooting), player three as small forward (versatile inside player), player four as power forward (strong rebounding forward), player five as post/centre (inside score rebounder). The objectives of the basketball game are to produce as many numbers as possible by entering the ball into the opponent's ring and preventing or blocking the opponent's game from scoring. Besides being a team or squad game, basketball games also require good individual skills from each player. Basketball game has basic techniques such as: (1) passing and catching; (2) Dribbling; (3) Shooting; (4) Ball Handling; and (5) Rebounding. One of the basic techniques that must be mastered is ball handling, this is because athletes have the good technique ball handling, then 


\section{JIPES}

Journal of Indonesian Physical Education and Sport

P-ISSN 2442-4900 | E-ISSN 2461-1271

Vol. 6, No.2, December 2020, page 01-10

it will be easy to master the other basic techniques and can be superior to other athletes. Moreover, ball handling is techniques that practice using high speed and do it with the right timing. This is very necessary to break defense from the opponent.

The results of observations by researchers when basketball athlete do the exercises and reviewing videos during practice and matches. So the researchers described that problems that affect basketball ball handling technique divided into two problems, including from the coaches and from the athletes themselves. The coaches include: (1) Lack of knowledge about ball handling technique, so that the coaches cannot develop individual skills from athlete; and (2) Ball handling technique less important than other basic basketball game techniques. Meanwhile, athletes include: (1) The difficulty of learning a ball handling technique, and need a good physique; (2) Training of ball handling techniques is saturating, because must be done repetitively; and (3) Timing in improper ball handling.

Based on the explanation above, it is necessary to use research model training ball handling for basketball athlete senior high school. In addition, this research will be adjusted to the concept and the limit researchers in development model training ball handling for basketball which is still lacking, so a development model training ball handling this basketball is required. development model training ball handling this basketball juga adapted to the stage of growth and development basketball athlete tingkatan senior high school, so that athletes grow and achieves according to his age. As for what needs to be considered in development model training this ball handling as follows: (1) Development individual skill athlete to even out individual skill abilities; (2) Give the opportunity for athletes to train harder at their training; and (3) Give spesific tools to make its abilities more effective and progressive.

Development model training ball handling product has the following new things: (1) This model training ball handling made with added speed, so it takes a good physique and error rate in ball handling expected to be minimized; (2) Mastery of correct ball handling techniques in deciding the timing that should be used in the match and there is guarding from opposing players; and (3) This model training ball handling arranged systematically from the easiest to the most difficult.

\section{METHOD}

The research method implemented in Senior High School to be precise at 3 (three) Senior High School in Cirebon Regency. The time of this research refers to research and development from Borg and Gall it takes two months, which is between February - April 2019. Development model training ball handling basketball which will be compiled and developed in the form of modification and effectiveness of movements in form ball handling training drill basketball to be precise 30 (thirty) training drill ball handling basketball for basketball athlete in Senior High School. These research and development steps refer to Borg. W. R \& Gall. M. D. The research using qualitative and quantitative approaches, with research design pra-eksperimental which compares with the situation before and after using the new system (before-after), in this case there is an experimental group. Thus the preexperimental model can be described as follows. 
Vol. 6, No.2, December 2020, page 01-10

\begin{tabular}{|c|c|c|c|}
\hline Subyek & Pre-test & treatment & Post-test \\
\hline $\mathrm{R}$ & $\mathrm{O}_{1}$ & $\mathrm{X}$ & $\mathrm{O}_{2}$ \\
\hline
\end{tabular}

\section{RESULTS AND DISCUSSION}

The results of the needs analysis can be seen that : (1) $100 \%$ athlete really like basketball training; (2) $68 \%$ athlete really like offense movement technique; (3) $27 \%$ athlete prefer to basketball training with basketball ball handling concept; (4) $18 \%$ athletes never get basketball ball handling training material with effective movement and high speed; (5) 79 $\%$ athlete are very bored when given repeated ball handling material.

After doing the data collection stage and making draft ball handling training model for basketball athlete in Senior High School, next is to do an expert test for get the feasibility or validity of the model made with direct expert judgment. The conclusions from the expert test conducted in 30 draft ball handling training model, all feasibility / valid to use.

\section{Model Effectiveness (trials)}

\section{a. First Stage Results / Small Group Trials}

The results of small group trials conducted on 30 basketball ball handling training models that were evaluated by experts showed that all models were valid, but must be adjusted to the characteristics of students.

After that, testing the significance of the effectiveness and efficiency of the new training model was carried out through the experimental model (before-after). In this experiment, the researchers used assessment data from 10 respondents / athletes on the effectiveness of the old training model shown in the table below, while the effectiveness of the new basketball ball handling training model is shown in the following table.

\section{Results of the Old Training Model Assessment}

\begin{tabular}{|c|c|c|c|c|c|}
\hline No & $\begin{array}{c}\text { Total Indicator } \\
\text { Assessment }\end{array}$ & Score & x $100 \%$ & Category & Meaning \\
\hline 1 & 20 & 0,63 & 63 & Good & Pass \\
\hline 2 & 21 & 0,66 & 66 & Good & Pass \\
\hline 3 & 25 & 0,78 & 78 & Good & Pass \\
\hline 4 & 19 & 0,59 & 59 & Enough & Not pass \\
\hline 5 & 24 & 0,75 & 75 & Good & pass \\
\hline 6 & 18 & 0,56 & 56 & Enough & Not pass \\
\hline 7 & 19 & 0,59 & 59 & Enough & Not pass \\
\hline 8 & 22 & 0,69 & 69 & Good & Pass \\
\hline 9 & 23 & 0,72 & 72 & Good & Pass \\
\hline 10 & 17 & 0,53 & 53 & Enough & Not pass \\
\hline Total & 208 & & & & \\
Athlete & & & & &
\end{tabular}


Score

To calculate the average effectiveness of the old training model, we must first determine the ideal score for that training model:

Ideal score: 1 x 4 x 8 x $10=320$

Information :

1: The highest answer score

4: Four points of assessment indicators

8: Eight stages of movement

10: Ten respondents

Based on the table above, the amount of data obtained $=208$. Thus the effectiveness of the old training model as a whole $=208: 320=0.65$ or $65 \%$ of the expected criteria.

\section{Results of the Assessment of the Basketball Ball Handling Training Model}

\begin{tabular}{|c|c|c|c|c|c|}
\hline No & $\begin{array}{c}\text { Total Indicator } \\
\text { Assessment }\end{array}$ & Score & x $100 \%$ & Category & Meaning \\
\hline 1 & 26 & 0,81 & 81 & Very good & Pass \\
\hline 2 & 27 & 0,84 & 84 & Very good & Pass \\
\hline 3 & 30 & 0,94 & 94 & Very good & Pass \\
\hline 4 & 26 & 0,81 & 81 & Very good & Pass \\
\hline 5 & 28 & 0,88 & 88 & Very good & Pass \\
\hline 6 & 24 & 0,75 & 75 & Good & Pass \\
\hline 7 & 25 & 0,78 & 78 & Good & Pass \\
\hline 8 & 29 & 0,91 & 91 & Very good & Pass \\
\hline 9 & 28 & 0,88 & 88 & Very good & Pass \\
\hline 10 & 21 & 0,66 & 66 & Good & Pass \\
\hline $\begin{array}{c}\text { Total } \\
\text { Athlete } \\
\text { Score }\end{array}$ & 264 & & & & \\
\cline { 1 - 3 } & & & & & \\
\end{tabular}

In order to calculate the average effectiveness of the new training model, we must first determine the ideal score for that training model:

Ideal score: 1 x 4 × 8 x $10=320$

Information :

1: The highest answer score

4: Four points of assessment indicators

8: Eight stages of movement

10: Ten respondents

Based on the table above, the total data obtained $=264$. Thus the effectiveness of the new training model as a whole $=264: 320=0.83$ or $83 \%$ of the expected criteria.

The comparison of the old training model with the new basketball ball handling training model is shown in the table below: 
Vol. 6, No.2, December 2020, page 01-10

\begin{tabular}{|c|c|c|}
\hline $\begin{array}{c}\text { Old Training } \\
\text { Model }\end{array}$ & $\begin{array}{c}\text { Aspects of Psychomotor Assessment } \\
\text { of Basketball Ball Handling }\end{array}$ & $\begin{array}{c}\text { New Training } \\
\text { Model }\end{array}$ \\
\hline 65,00 & Total Movement Indicator & 82,50 \\
\hline 65,00 & Average & 82,50 \\
\hline
\end{tabular}

To prove the significance of the differences between the old and new training models, it was necessary to test statistically with a correlated t-test. The formula used is as follows:

$$
t=\frac{\bar{x}_{1}-\bar{x}_{2}}{\sqrt{\frac{s_{1}^{2}}{n_{1}}+\frac{s_{2}^{2}}{n_{2}}-2 r\left(\frac{s_{1}}{\sqrt{n_{1}}}\right)\left(\frac{s_{2}}{\sqrt{n_{2}}}\right)}}
$$

\section{Correlated Model Performance Values}

\begin{tabular}{|c|c|c|}
\hline No & X1 (Old Training Model) & X2 (New Training Model) \\
\hline 1 & 20 & 26 \\
\hline 2 & 21 & 27 \\
\hline 3 & 25 & 30 \\
\hline 4 & 19 & 26 \\
\hline 5 & 24 & 28 \\
\hline 6 & 18 & 24 \\
\hline 7 & 19 & 25 \\
\hline 8 & 22 & 29 \\
\hline 9 & 23 & 28 \\
\hline 10 & 17 & 21 \\
\hline$\sum X$ & 208 & 264 \\
\hline $\bar{X}$ & 20,8 & 26,4 \\
\hline$S$ & 2,66 & 2,63 \\
\hline$S 2$ & 7,07 & 6,93 \\
\hline $\mathrm{r}$ & 1,00 & 1,00 \\
\hline
\end{tabular}

H0 : The effectiveness of the new training model is less or the same as the old training model

Ha : The effectiveness of the new training model is better than the old training model

$\mathrm{H} 0 \quad: \mathrm{X} 1 \leq \mathrm{X} 2$

$\mathrm{Ha} \quad: \mathrm{X} 1>\mathrm{X} 2$

Testing used in this study was t-test on right-side test. This right side test used because the alternative hypothesis (Ha) was "better". 


\section{נIPES} Journal of Indonesian Physical Education and Sport

P-ISSN 2442-4900 | E-ISSN 2461-1271

Vol. 6, No.2, December 2020, page 01-10

$$
\begin{aligned}
t & =\frac{\bar{x}_{1}-\bar{x}_{2}}{\sqrt{\frac{s_{1}^{2}}{n_{1}}+\frac{s_{2}^{2}}{n_{2}}-2 r\left(\frac{s_{1}}{\sqrt{n_{1}}}\right)\left(\frac{s_{2}}{\sqrt{n_{2}}}\right)}}=\frac{20,8-26,4}{\sqrt{\frac{7,07}{10}+\frac{6,93}{10}-2(1)\left(\frac{2,66}{\sqrt{10}}\right)\left(\frac{2,63}{\sqrt{10}}\right)}}= \\
& =\frac{-5,6}{\sqrt{0,70+0,69-2(0,84)(0,83)}}=\frac{-5,6}{\sqrt{1,39-1,39}}=\frac{-5,6}{0}=-5,6
\end{aligned}
$$

To make a decision, whether the comparison is significant or not, then the calculated t value needs to be compared with the $\mathrm{t}$ table value using $\mathrm{dk} \mathrm{n}-2=8$. Based on table II regarding the values in the $\mathrm{t}$ distribution, if $\mathrm{dk}=8$, for one-party test with an error level of $5 \%$, then the value of $t$ table $=1,86$. If the $t$ value lies in the receiving area of $\mathrm{Ha}$, then Ha which states that the new training model is better than the old training model can be accepted. Based on the calculation, it turns out that the $t$ count was 5.6 which indicates that the value lied in the area of acceptance for $\mathrm{Ha}$ or rejection of H0. Thus it can be concluded that there was a significant difference (can be generalized) in the effectiveness of the new and old training models, where the new training model was better than the old training model regarding ball handling material for high school basketball athletes.

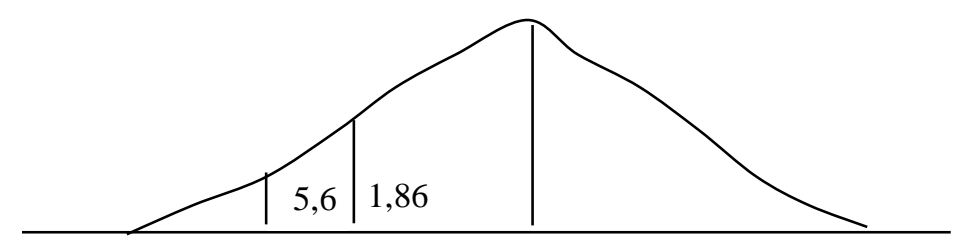

The next step after the model underwent a stage II revision from the expert was testing the model to a large group using research subjects as many as 60 high school basketball athletes in Cirebon Regency consisting of 30 basketball athletes in the experimental group and 30 basketball athletes in the control group.

Assessment data from 60 respondents / basketball athletes on the effectiveness of the basketball ball handling training model is shown in the following table:

\begin{tabular}{|c|c|c|c|}
\hline Name & Pre-Test $\left(\mathrm{O}_{1}\right)$ & Name & Post-Test $\left(\mathrm{O}_{2}\right)$ \\
\hline 1 & 27 & 1 & 28 \\
\hline 2 & 26 & 2 & 27 \\
\hline 3 & 25 & 3 & 26 \\
\hline 4 & 27 & 4 & 27 \\
\hline 5 & 29 & 5 & 30 \\
\hline 6 & 25 & 6 & 26 \\
\hline 7 & 29 & 7 & 30 \\
\hline 8 & 24 & 8 & 26 \\
\hline 9 & 25 & 9 & 25 \\
\hline 10 & 29 & 10 & 30 \\
\hline 11 & 24 & 11 & 25 \\
\hline
\end{tabular}




\section{$\because$ :. \\ P-ISSN 2442-4900 | E-ISSN 2461-1271 \\ Vol. 6, No.2, December 2020, page 01-10}

\begin{tabular}{|c|c|c|c|}
\hline 12 & 27 & 12 & 28 \\
\hline 13 & 27 & 13 & 27 \\
\hline 14 & 25 & 14 & 25 \\
\hline 15 & 29 & 15 & 30 \\
\hline 16 & 26 & 16 & 28 \\
\hline 17 & 25 & 17 & 25 \\
\hline 18 & 26 & 18 & 27 \\
\hline 19 & 24 & 19 & 29 \\
\hline 20 & 26 & 20 & 26 \\
\hline 21 & 27 & 21 & 28 \\
\hline 22 & 27 & 22 & 30 \\
\hline 23 & 28 & 23 & 29 \\
\hline 24 & 24 & 24 & 25 \\
\hline 25 & 24 & 25 & 28 \\
\hline 26 & 24 & 26 & 25 \\
\hline 27 & 28 & 27 & 29 \\
\hline 28 & 23 & 28 & 24 \\
\hline 29 & 24 & 29 & 26 \\
\hline 30 & 27 & 30 & 29 \\
\hline Total & 781 & Total & 818 \\
\hline Average & 50,39 & Average & 52,77 \\
\hline
\end{tabular}

The results of the pre-test showed that the total score of the ball handling technique for high school basketball athletes was 781 and the average was 50.39. After that, the treatment was given to basketball athletes using the ball handling basketball models that have been developed. After the treatment was given, the subject was tested again with the same test as the previous basketball ball handling technique test. Post-test or final test was measured to determine whether there was an increase in the ability of basketball ball handling techniques in basketball athletes after giving treatment in the form of basketball ball handling training models. The results of the post test showed that the total score of respondent was 818 and the was average of 52.77 .

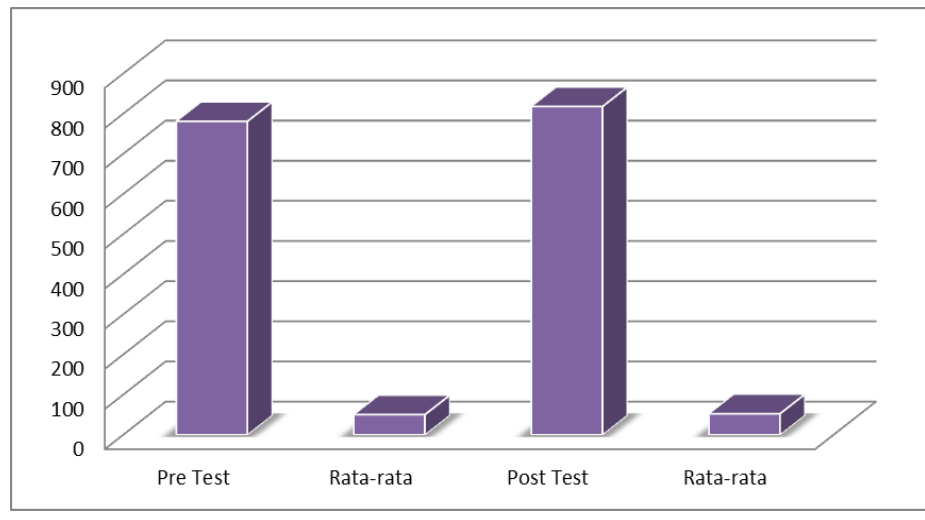


Vol. 6, No.2, December 2020, page 01-10

\section{CONCLUSION}

Based on the data obtained, from the results of small group trials and large group trials as well as discussion of research results, it can be concluded that:

1. With the development of a basketball ball handling technique training model, it can improve the ability of high school basketball athletes.

2. Through the development of this training model, it can help basketball coaches to provide basketball ball handling exercises effectively and efficiently for high school basketball athletes.

\section{REFERENCES}

Amber, Vic. (2009). Petunjuk untuk Pelatih \& Pemain Bola Basket. Bandung: Pionir Jaya. Arias-Estero, Jose' L., Francisco M. Argudo, dan Jose' I Alonso. (2018). “One-on-one Situation Decision-Making According to Equipment in youth Basketball”, International Journal of Sports Science \& Coaching, Vol. 13 (1).

Asdep Pengelolaan Pembinaan Sentra dan Sekolah Khusus Olahraga. (2017) Petunjuk Pelaksanaan Tes Ketrampilan dan Norma PPLP di Indonesia. Jakarta: Deputi Bidang Pembudayaan Olahraga KEMENPORA.

Burns, Brian dan Mark Dunning. (2010) "Skills in Motion Basketball Step-by-Step". (New York: The Rosen Publishing Group)

Canlı, Umut dan Çalık Veli Koçak, (2018). "The Relationship of Shooting Skill with Functional Movement Performance and Attention Level of Basketball Players", Journal of Education and Training Studies, Vol. 6 (12a).

Creswell, John W. (2016) Research Design, Pendekatan Metode Kualitatif, Kuantitatif, dan Campuran. Yogyakarta: Pustaka Pelajar.

Garg, Rakesh. (2016) "Methodology for Research I", Indian Journal of Anaesthesia, Vol. 60 (9).

Hanna, Sura Jamil dan Saad Alla Abass. (2015) "Comparison in Some Kinematic Variables of Lay Up Basketball of Older and Young Players", Journal of Human Sport \& Exercise, Vol. 10.

Hantula, Richard. (2012). Science at Work in Basketball. New York: Marshall Cavendish.

Hay, J.G., (2007) "The Biomechanics of Sports Techniq", dalam The effects of Increased Shooting Distance in the Basketball Jump Shot diedit oleh Stuart Miller dan Roger M. Bartlett. Journal of Sports Science, Vol. 11.

Hyysalo, Sampsa. (2009). "User Innovation and Everyday Practices: Micro-Innovation in Sports Industry Development”, Journal Compilation, Vol. 39 (3).

Joyce, Bruce, Marsha Weil, dan Emily Calhoun. (2009). Models of Teaching (Eight Edition). New Jersey: Upper Saddle River.

Korjenić, Azer, Emir Spahalić, dan Samir Lerić. (2017). “Analysis of Quantitive Changes of Researched Antropological Spaces in Basketball Players at Junior Ages", Journal Sportski Logos. 
Kosasih, Danny. (2010). Fundamental Basketball, First Step To Win. Semarang: Karangturi Media.

Maksum, Ali. (2012). Metodologi Penelitian dalam Olahraga. Surabaya: Unesa University Press.

Marmarinos, Christos. et. al. (2016). "Efficacy of the (Pick and Roll) Offense in Top Level European Basketball Teams", Journal of Human Kinetics, Vol. 51.

National Alliance for Youth Sports dan Greg Bach. (2007). Coaching Basketball For Dummies. Indianapolis: Wiley Publishing, Inc.

Okazaki, Victor Hugo Alves dan André Luiz Félix Rodacki. (2012). "Increased Distance of Shooting on Basketball Jump Shoot", Journal of Sports Science and Medicine, Vol. 11.

Okubo, Hiroki dan Mont Hubbard. (2015). "Kinematics of Arm Joint Motions in Basketball Shooting". 7th Asia-Pacific Congress on Sports Technology, Procedia Engineering 112.

Oliver, John. (2009). Dasar-dasar Bola Basket. Bandung: Pakar Raya.

Paye, Burral dan Patrick Paye. (2013). Youth Basketball Drills, Second Edition. Champaign: Human Kinetics.

Podmenik, Nadja et. al. (2017). "The Effect of Shooting Range on The Dynamics of Limbs Angular Velocities of The Basketball Shot", Journal of Kinesiology, Vol. 49 (1).

Prasetyo, Dedi Wahyu dan Yustinus Sukarmin. (2017). "Pengembangan Model Permainan untuk Pembelajaran Teknik Dasar Bola Basket di SMP”, Jurnal Keolahragaan, Vol. 5 (1).

Program Pascasarjana Universitas Negeri Jakarta. (2016) Buku Pedoman Penulisan Tesis dan Disertasi. Jakarta.

Rose, Lee H. (2013). Winning Basketball Fundamentals. Champaign: Human Kinetics.

Savas Seyfi, Mehmet Fatih Yüksel, dan Ahmet Uzun, (2018) "The Effects of Rapid Strength and Shooting Training Applied to Professional Basketball Players on the Shot Percentage Level", Universal Journal of Educational Research, Vol. 6 (7).

Shortridge, Ashton, Kirk Goldsberry dan Matthew Adams. (2014). "Creating Space to Shoot: Quantifying Spatial Relative Field Goal Efficiency in Basketball”, JQAS, Vol. 10 (3).

Sobko, Irina. (2015). “An Innovative Method of Managing the Training Process of Qualified Basketball Players with Hearing Impairment", Journal of Physical Education and Sport ${ }^{\circledR}($ JPES), Vol. 15 (4).

Sugiyono. (2011). Metode Penelitian Kuantitatif, Kualitatif dan R \& D. Bandung: Alfabeta.

Sulaiman, Iman. (2015). "Pengembangan Model Latihan Menembak pada Permainan Bola Basket", Disertasi, Pendidikan Olahraga Universitas Negeri Jakarta.

Sulaiman, Iman dan Ahmad Rizaldy Fajrin. (2018). "Pengembangan Model Latihan Menyerang pada Permainan Bola Basket”, Gladi Jurnal Ilmu Keolahragaan UNJ, Vol. 09 (01). 